\title{
Bioprospecting of Kerangas Forest as Natural Medicine Material Sources: Screening Phytochemistry Compound of Kerangas Forest Tree Species
}

\author{
Kissinger, Ahmad Yamani, Gusti Ar Thamrin, and Rina Muhayah Np
}

Faculty of Forest, Lambung Mangkurat University, Indonesia

\begin{abstract}
Bioprospecting is an effort to create a value for biodiversity. Bioactivity identification of tree species is an important step to get high economic value from Kerangas forest. Screening bioactivity of plants was conducted by ethnobotanical survey and qualitative phytochemistry compound tests. Data collection in the ethnobotanical survey was conducted using a structured interview. Dried leaves and barks of selected trees from Kerangas forest were tested for qualitative phythochemistry compound. Qualitative phytochemistry analyzed by detected of color visualization. There are a total of 42 plants located in heath forest, 38 species of which are used by the people as a medicine (90.48\%). There are 10 species of tree that is always found in various locations all in heath forest. 8 tree species are commonly used as a medicine by community. Result showed that parts of selected trees from Kerangas forest had various phythochemistry compounds. It can be concluded that methanol extract of Kerangas tree species have potential bioactivities. Phytochemical content of some trees species may have potential as antibacterial, antidiabetic, antiinflamation, antioxidant, anti-plasmodium, asthma treatment and vitality.
\end{abstract}

Key words: ethnobotanical, Kerangas forest, phytochemistry, tree species

\section{INTRODUCTION}

Kerangas (heath forest) is a type of land which is characterized by poor soil nutrient of podsol with soil material that is rich in quartz sand, low $\mathrm{pH}$ and often has a thin layer of peat above ground level. Vegetation that grew is too limited and has a special character as a result of adaptation to the limiting environment (Bruenig, 1995). The International Union for the Conservation of Nature-World Conservation Union (IUCN) has categorized the status of heath forest area as vulnerable.

General perspective consider that the existence of heath forest does not significantly provide direct economic benefits to society and development. The case in South Kalimantan, from the heath forest only wood is collected and material sources for dug outs. Utilization of the heath forest has damaged vegetation, land and environment.

Correspondence: Kissinger. Faculty of Forest,

Lambung Mangkurat University

Email: durror2ali@yahoo.com
Heath forest ecological damage and its impact to the community must be addressed with heath forest conservation action.

The new paradigm of biodiversity conservation is how we can take advantage of biodiversity which is relatively save to environment. Utilization of biodiversity should not be permanently damaging natural resources and have high value of potential economic benefits from sustainable of natural resources (Zuhud, 2007).

Bioprospecting is a process of finding benefits or added value in the form of materials or services of natural resources. The potential benefits and heath forest ecological characteristics can be used as one of the priority conservation action. Nature is the source of many treatment (Sneader, 1996), and ethno pharmacology or traditional medicine to contribute knowledge about the medicinal ingredient such as morphine, quinine, dogitoxin, ephedra and tubocurarine (Harvey and Gericke, 2011).

Bioprospecting is a choice based on natural management of the heath forest resource utilization. Ability of heath forest to become a source of treatment material 
associated with the basic theory that the process of secondary metabolites that produce certain phytochemical compounds related or can be triggered by stress or environmental stress. Bioprospecting is a choice based on natural management of the heath forest resource utilization. Limitations character of health making plant species there adapt and trigger the process of secondary metabolites.

This management option of bioprospecting when arranged properly will potentially be the choice of sustainable natural resource management. Heath forest management approach based on bioprospecting and utilization of forest resources development is a form of management that is in line with the new paradigms of conservation of biodiversity. Exploiting bioactivity materials of plants as an alternative to the use of a relatively less destructive and more environmentally friendly. This study tried to find the bioactivity of some plants in heath forest. The discovery of the bioactivity of plant in heath forest implemented based approach ethnobotany knowledge of forest communities and the results of the preliminary identification of qualitative phytochemical compounds from heath forest plants.

Results from this study are expected to be as important information for the development of bioactivity of heath forest. This research will further enrich the knowledge of the heath forest biodiversity for the conservation and development of the small business community in the field of health and medicine on the basis of traditional knowledge and empirical evidence of science and technology.

\section{MATERIALS AND METHODS}

\section{Materials and Tools}

Materials and tools used in this study consisted of materials and tools for ethnobotany survey, sample collection and laboratory analysis for phytochemical compounds. Materials in this research are medicinal plants in the kerangas forest, community around the kerangas forest. Tools in this research are questionnaires, camera, GPS, container samples. The plant materials used are the leaves and barks of some tree species of kerangas forest. Materials used in laboratory analysis are methanol, leaves and bark of plant, chemical material for qualitative phytochemistry. Chemical testing conducted at the laboratory of Study Center of Biopharmaca Bogor Agricultural Univ.

\section{Data Collection and Analysis}

The scope of research activities includes an inventory of field and laboratory testing. Ethnobotany research locations covering heath forest located in Guntung Ujung Village Banjar district of South Kalimantan, Sanggu Village South Barito district, and East Kotawaringin district of Central Kalimantan. A test of qualitative phytochemical was conducted in the laboratory of Study Center of Biopharmaca Bogor Agricultural Univ.

Stages of activities undertaken in the selection of tree species that have the potential as natural resource for diabetes cure are as follow:

1) Survey of ethnobotany: Ethnobotany survey aims to make inventory of the types of tree from heath forest potential as medicinal plant. Data collection was conducted using a structured interview (Rahayu et al. 2008). Data were descriptively analyzed by using matrix tabulation.

2) Identifying qualitative phytochemical compounds (Harborne, 1987). The test of qualitative phytochemical was conducted by using color visualization.

\section{Phytochemical Analysis}

Test for Alkaloids: To the test solution in $10 \mathrm{ml}$ methanol, add $1 \%$ (w/v) $\mathrm{HCl}$ and any of Mayor's reagents, Wagner's reagent or Dragendroff reagent (6 drops). A creamish or brownish red or orange precipitate indicated the presence of alkaloids.

Test for Flavonoids: $5 \mathrm{ml}$ of dilute ammonia solution was added to a portion of the aqueous filtrate of each plant extract followed by addition of concentrated $\mathrm{H}_{2} \mathrm{SO}_{4}$. A yellow color in each extract indicated the presence of flavonoids. The yellow color disappeared on standing. Few drops of $1 \%$ aluminum solution were added to portion of each filtrate. A yellow color indicates the 
presence of flavonoids. A portion of the powdered plant sample was in each case heated with $10 \mathrm{ml}$ of ethyl acetate over a steam bath for $3 \mathrm{~min}$. The mixture was filtered and $4 \mathrm{ml}$ of the filtrate was shaken with $1 \mathrm{ml}$ of dilute ammonia solution. A yellow color indicates opposite test for flavonoids

Test for Phenolhydroquinon: About 500 $\mathrm{mg}$ of powdered sampel add with $50 \mathrm{~mL}$ of water and boiled for 5 minutes. 3 drops of concentrated sample was added to form layer. Few drops of $\mathrm{NaOH} 1 \mathrm{~N}$. The red color indicated the presence of phenol hydroquinone.

Test for Steroids: About $500 \mathrm{mg}$ sample powder mixed with $20 \mathrm{~mL}$ eter and maseration for 2 hours. 3 drops of concentrated sample was added to form layer. Few drops of glasial asetat acid- $\mathrm{H}_{2} \mathrm{SO}_{4}$ (Lieberman-Bourchard reagent) to the concentrated sample. The red color indicated the presence of steroid.

Test for Triterpenoids: $5 \mathrm{ml}$ of each extract mixed with $2 \mathrm{ml}$ of chloroform, and 3 $\mathrm{ml}$ concentrated $\mathrm{H}_{2} \mathrm{SO}_{4}$ was carefully added to form a layer. A reddish brown color of the inter face was formed to show positive results for the presence of triterpenoids.

Test for Tannins: About $0.5 \mathrm{~g}$ of the sample of plant was dried and powdered samples was boiled in $20 \mathrm{ml}$ of water in a test tube and then filtered. A few drops of $0.1 \%$ ferric chloride was added and observed for brownish green or a blue-black colouration.

Test for Saponins: About $2 \mathrm{~g}$ of the powdered sample was boiled in $20 \mathrm{ml}$ of distilled water in a water bath and filtered. $10 \mathrm{ml}$ of the filtrate was mixed with $5 \mathrm{ml}$ of distilled water and shaken vigorously for a stable persistent froth, which indicates the presence of saponins.

\section{RESULTS AND DISCUSSION}

\section{The ethnobotany knowledge about medicinal trees species of kerangas forest}

Based on the information obtained from the local community in heath forest, there are a total of 42 plants located in heath forest, 38 species of which are used by the people as a medicine $(90.48 \%)$. There are 10 species of tree that is always found in various locations all in heath forest. Table 1 describes 10 species of trees that are available in heath forest and its benefits for the medicine based on information obtained from local society.

Based on the results shown in Table 1, there are eight tree species that are commonly used as a medicine by community, while two other types are still unexplored. Trees native species that used as medicinal plant are Adina minutiflora, Combretocarpus rotundatus, Cratoxylon arborescens, Melaleuca cajuputi, Shorea belangeran, Tristaniopsis obovata, Vitex pubescens. The benefits obtained from the plants sufficiently varied as analgesic, antibacterial, antidiabetic, anti-plasmodium, vitality, cough and others. These findings indicate that the adaptability of a species in a limited land (forest heath) are associated with the potential of trees as a natural medicine.

Table 1. Potential utilization of kerangas forest trees species as natural medicine

\begin{tabular}{|c|l|l|l|}
\hline No & \multicolumn{1}{|c|}{ Species } & \multicolumn{1}{|c|}{ Utilization } & \multicolumn{1}{|c|}{$\begin{array}{c}\text { Parts of trees that } \\
\text { used }\end{array}$} \\
\hline 1 & Akasia (Acacia mangium) & unexplored & unexplored \\
\hline 2 & Alaban (Vitex pubescens) & stomach pains, wound, fever & Leaves and bark \\
\hline 3 & Bati-bati (Adina minutiflora) & stomach pains & Leaves \\
\hline 4 & Belangiran (Shorea belangeran) & $\begin{array}{l}\text { malaria, diabetes, diarrhea, } \\
\text { stamina, antidote }\end{array}$ & Leaves, bark and root \\
\hline 5 & Bintangur (Callophylum lowii) & analgesic, festering scars & Leaves and bark \\
\hline
\end{tabular}




\begin{tabular}{|c|l|l|l|}
\hline No & Species & Utilization & $\begin{array}{c}\text { Parts of trees that } \\
\text { used }\end{array}$ \\
\hline 6 & Galam (Melaleuca cajuputi) & $\begin{array}{l}\text { stomach pains, wound, } \\
\text { analgesic }\end{array}$ & Leaves and fruit \\
\hline 7 & $\begin{array}{l}\text { Gerunggang/irat (Cratoxylon } \\
\text { arborescens) }\end{array}$ & $\begin{array}{l}\text { Fever, cough, stomach pain, } \\
\text { diarrhea, wound. }\end{array}$ & Leaves and bark \\
\hline 8 & $\begin{array}{l}\text { Merapat (Combretocarpus } \\
\text { rotundatus) }\end{array}$ & unexplored & unexplored \\
\hline 9 & Palawan (Tristaniopsis obovata) & $\begin{array}{l}\text { stomach pain, lever, mag, } \\
\text { stamina }\end{array}$ & $\begin{array}{l}\text { Leaves, bark, root } \\
\text { and water from stem }\end{array}$ \\
\hline 10 & Rambuhatap (Baeckea frutescens) & $\begin{array}{l}\text { Stomach pain, analgesic, } \\
\text { antiacne }\end{array}$ & Leaves \\
\hline
\end{tabular}

\section{Phytochemical compounds of some heath forest trees}

Identifying phytochemical compounds conducted on 10 species of trees. Selection of the 10 trees species is based on the existence of species in all area of heath forest research sites. Results of phytochemical compounds identification of some species of trees are always found in heath forest are shown in Table 2 .

Table 2. Phytochemistry compound of kerangas forest trees species

\begin{tabular}{|c|l|r|r|r|r|c|c|c|c|}
\hline No. & Plant species & $\mathbf{1}$ & $\mathbf{2}$ & $\mathbf{3}$ & $\mathbf{4}$ & $\mathbf{5}$ & $\mathbf{6}$ & $\mathbf{7}$ & Part of plant \\
\hline 1 & Akasia (Acacia mangium) & - & + & + & - & + & + & + & bark \\
\hline 2 & Alaban (Vitexpubescens) & - & + & + & + & + & + & - & leaves \\
\hline 3 & Bati-bati (Adina minutiflora) & - & + & + & + & + & + & + & leaves \\
\hline 4 & Belangiran (Shoreabelangeran) & + & + & + & - & + & + & + & bark \\
\hline 5 & Bintangur (Callophylumlowii) & - & + & + & + & + & + & + & leaves \\
\hline 6 & Galam (Melaleucaleucadendron) & + & + & + & + & + & + & + & leaves \\
\hline 7 & Irat (Cratoxylonarborescens) & - & + & + & + & + & + & + & bark \\
\hline 8 & Merapat (Combretocarpusrotundatus) & - & + & + & + & + & + & - & leaves \\
\hline 9 & Palawan (Tristaniopsisobovata) & - & + & + & + & + & + & + & leaves \\
\hline 10 & Rambuhatap (Backeafrutescens) & - & + & + & + & + & + & + & leaves \\
\hline
\end{tabular}

Description: 1.Alcaloid, 2.Flavonoid, 3.Phenolhidroquinon, 4.Steroid, 5.Triterpenoid, 6.Tanin, 7. Saponin

Phytochemical analysis is very useful in the evaluation of some active biological components of medicinal plants (Sundaram et al. 2011). The results are shown in Table 2 indicate that almost all samples containing plavonoid, phenolhidroquinon and tannins. Phytochemical content of some tree species may have potential as an antioxidant, antibacterial, antiplasmodium, antidiabetic and other bioactivities. Flavonoids have potential as antibacterial and antidiabetic (Jung et al. 2006). According to Naim (2004) cited Rambe et al. (2012) flavonoids have lipophilic properties so that possible damage cell membranes of bacteria. The content of flavonoids in Acalyphaindica plant extracts is as potential antidiabetic (Still et al. 2011). Flavonoids from plant have used as alternatives in treatment of type 2 diabetes (Hussain and Marouf 2013). Flavonoids are phenolic compound that act as primary antioxidants or free radical scavengers (Seth and Sanin, 2010). Many antioxidant capacities associated with the flavonoid (Sarastani et al. 2002; Arini et al. 2003). Epidemiological studies have shown that flavonoids and carotenoids intake are inversely related to mortality from coronary heart diseases and to the incidence of heart attacks (Donald and Cristobal, 2006). 
Flavonoids have been referred to as nature's biological response modifiers because of strong experimental evidence of their ability to modify the body's reaction to allergies, virus and carcinogens. They show antiallergic, anti-inflammatory, antimicrobial and anticancer activity (Seth and Sarin, 2010). Flavonoid has potential as asthma treatments (Yang et al. 2012).

The presence of flavonoids and tannins in plants are likely to be responsible for the free radical scavenging activity. Flavonoids and tannins are phenolic compounds and plant phenolics are a major group of compounds that act as primary antioxidants or free radical scavengers. These findings give credence to the traditional medicinal application of the leaves as remedies for sores, rash and be witchment, internal and external wounds and infections. Many antioxidant capacities associated with phenol hydroquinone, plavonoid and tannin (Sarastani et al. 2002; Arini et al. 2003). Tannin contained in some foods have potential as an antidiabetic (Kunyanga et al. 2011). Tannin associated with adhesion ability to inactivate microbes, enzymes and transport proteins in the cell membrane.

Alkaloids contained by two types of stem Belangiran ( $S$. belangeran) tree bark and leaves of Galam (Melaleuca cajuputi). Alkaloids are a class of organic compounds that most found in nature. Almost all alkaloids derived from plants and widespread in many kinds of higher plants. Most of the alkaloid found in dicotyledonous plants while monocotyledonous and Pteridofita contain alkaloids with a lower rate. Alkaloid used as an antibacterial and antiamoeba (Hasibuan and Nainggolan, 2007). Alkaloid from plant (C. sympodialis extract) had using as medicinal for asthma treatments, antiinflammation, anti-allergic (Bezerra-Santos et al. 2012)

Saponins possess hypocholesterolemic and antidiabetic properties. Saponins have used for asthma treatment (Yuan et al. 2011). Terpenoid compounds known to be active against bacteria, fungi, viruses and protozoa. The antimicrobial mechanism of terpenoid associated with damage to cell membranes by lipophilic compounds. terpenodis have potential as antibacterial and antidiabetic (Jung et al. 2006). Steroids have antiinflammatory effects (Seth and Sarin, 2010).

There are relationship between phytochemical compounds and bioactivity of plants. It also been widely observed and accepted that the medicinal value of plants lies in the bioactive phyto components present in the plants (Veeramuthu et al. 2006). Relating to the information from the society ethnobotany knowledge and phytochemical content, there are indications that plants from kerangas forest have the capacity as an antibacterial (stomach pain, diarrhea, wound), anti-inflammation (analgesic, fever), asthma treatment (cough), anti-plasmodium (malaria), antioxidant (stamina, vitality) and anti-diabetic. All information about a medicine based on society ethnobotany knowledge and screening plant phytochemical compounds are preliminary findings that indicate potential heath forest as a source of natural medicine and become an important information for the development of bioprospecting in heath forest.

\section{CONCLUSION}

There are a total of 42 plants located in heath forest, 38 species of which are used by the public as a medicine $(90.48 \%)$. The number of tree species that are always available in all locations of heath forest are 10 species. There are 8 species of which are commonly used by the community as a medicine. The benefits obtained from 10 species are as analgesic, antibacterial, antidiabetic, anti-plasmodium, asthma treatment and vitality.

The result of this research indicates that there is a relationship between the use of plants as a medicinal treatment by the community with the phytochemical content of plants. Almost all plants in heath fores contain flavonoids, phenols hydroquinone and tannins. Alkaloid contained only by two species of trees, bark stem of Belangiran (S.belangeran) and leaves of Galam (Melaleuca cajuputi). Phytochemical content of some tree species may have potential as an antioxidant, antibacterial, antiplasmodium, 
asthma treatment, antidiabetic or other bioactivity.

Ethnobotany knowledge of society and screening plant phytochemical compounds are preliminary findings that indicate potential heath forest as a source of natural medicine and become an important information for the development of bioprospecting in heath forest. Utilization of leaves and bark of plants as a source is relatively safe cure to preserve the plant. The use of plant parts that can permanently damage the plants such as the roots, can be addressed with actions in situ breeding and plant population arrangements are relatively safe to be harvested. Advanced testing necessary to strengthen the evidence of potential bioactivity of trees in the forest heath.

\section{REFERENCE}

Arini S, Nurmawan D, Alfiani F, Hertiani T. 2003. Antioxidant capacity and levels of flavonoids extracted ethanol-water of fruit of mahkota dewa (Phaleria macrocarpa). Buletin Penalaran Mahasiswa UGM, 10 (1): 2-6.

Bezerra-Santos CR, Vieira-de-Abreu A, Vieira GC, Filho JR, Barbosa JM, Pires AL, Martins MA, Souza HS, BandeiraMelo C, Bozza PT, Piuvezam MR. 2012. Effectiveness of Cissampelos sympodialis and its isolated alkaloid warifteine in airway hyper reactivity and lung remodeling in a mouse model of asthma. Int Immunopharmacol, 13: 148-155.

Bruenig EF. 1995. Conservation and Management of Tropical Rain Forest: An Integrated Approached to Sustainability. CAB International.

Burlon GW, Ingold KU. 1984. B-Carotene, an unusual type of lipid antioxidant. Journal of Science, 224, 573.

Cetto AA, Jimenez JB, and Vaquez RC. 2008. Alfa-glukosidase inhibiting activity of some mexican used in the treatment of type 2 diabetes. Journal of ethnopharmacology, 116: 27-32

Donald RB, Cristobal M. 2006. Antioxidant activities of flavonoids. Journal of Agriculture, 52, 125-757.
Harborne, J.B., 1973. Phytochemical Methods London. Chapman and Hall Ltd.

Hasibuan P.A.Z. dan Nainggolan M. 2007. Penentuan sifat kimia fisika senyawa alkaloid hasil isolasi dari daun bandotan (Ageratum conyzoides Linn.) JURNAL PENELITIAN MIPA Volume 1, Nomor 1.

Hussain SA, Marouf BA. 2013. Flavonoids as alternatives in treatment of type 2 diabetes mellitus. Academia Journal of Medicinal Plants 1(2): 31-36.

http://www.academiapublishing.org/ajmp

Jung M. Park M. Lee HC. Kang Y-H. Kang ES, Kim SK. 2006. Antidiabetic Agents from Medicinal Plants. Current Medicinal Chemistry, 13: 1203-1218.

Kunyanga CN, Imungi JK, Okoth M, Momanyi, C. Biesalski HK. Vadivel V. 2011. Antioxidant and Antidiabetic Properties of Condensed Tannins in Acetonic Extract of Selected Raw and Processed Indigenous Food Ingredients from Kenya. Journal of Food Science, 76(4): C560-C567.

Lee MY, Ahn KS, Lim HS, Yuk JE, Kwon OK, Lee KY, Lee HK, Oh SR. 2012. Tiarellic acid attenuates airway hyper responsiveness and inflammation in a murine model of allergic asthma. Int Immunopharmacol, 12: 117-124.

Masih M, Banerjee T, Banerjee B. Pal A. 2011. Antidiabetic activity of Acalypha indica Linn. on normal and alloxan induced diabetic rats. International Journal of Pharmacy and Pharmaceutical Sciences, 3(3): 51-54.

Rahayu M, Sunarti S, Keim AP. 2008. Ethnobotani Study of Pandan Samak (Pandanusodoratissimus L.f.): The Utilization and role in supporting business in the family income at Ujung Kulon, Banten. BIODIVERSITAS, 9(4): 310-314.

Rambe KN, Pasaribu A, Bulan R. 2012. Antibacterial test of Methanol Leaf Extract from Salam Leaves (Sygyzium polyanthum) against Escherichia coli and Salmonella sp. Saintia Chemist Journal, 1(1): 35-39.

Sarastani D, Suwarna TS, Tien RM, Fardiaz D, Apriyanto P. 2002. Antioxidant Activities of Extracts and Seed Extract 
Fraction of Atung. Journal of Food Technology and Industry, 8(2): 149-156.

Sarjono PR. 2010. Activity of Kayu Manis

(Cinnamomum cassia) powder as an Alfa-

Glukosidase Inhibitory. Journal of Science and Mathematics, 18(2).

Seth R. Sarin R. 2010. Analysis of the Phytochemical Content and Antimicrobial Activity of Jatropha gossypifolia L. Arch. Appl. Sci. Res., 2 (5): 285-291

Sukandar D, Hermanto S, AlMabrur I. 2010. Antidiabetic activity of Ethyl Acetate Extract compounds of Pandan Wangi Leaves (Pandanus amaryllifolius Roxb.) Valensi. 1(6): 269-273.

Sulastri D, Rahmatini, Lipoeto NI, Edwar Z. 2010. Influence of Antioxidant Intake on Gene Expression eNOS3 Gene in Patients with Hypertension Minangkabau Ethnic. Indonesian Medical Magazine, 60(12).

Sundaram SM, Bharathi, Thirumalai, Pennarasi, Gowthamkumar, Sabarirajan, Premanand, Vishalanand, Mohsin. 2011. Studies on phytochemicals, antibacterial efficacy and antioxidant potency of Capparis sepiaria on enteric pathogens. International Journal of Biomolecules and Biomedicine (IJBB), 1(3): 1-7.
Sutedja L. 2003. Bioprospecting of Indonesia medicinal plant as a material of antidiabetic phytopharmacy. Chemical Research Center-LIPI.

Veeramuthu, D, Muniappan A. Savarimuthu I. 2006. Antimicrobial activity of some ethno medicinal plants used by paliyar tribe from Tamilnadu, India. $B M C$ Complementary and alternative Medicine, 6(35).

Yang N, Patil S, Zhuge J, Wen MC, Bolleddula J, Doddaga S, Goldfarb J, Sampson HA, Li XM. 2012. Glycyrrhiza uralensis flavonoids present in antiasthma formula, ASHMI(TM), inhibit memory $\mathrm{Th} 2$ responses in vitro and in vivo. Phytother Research.

Yuan X, Sun S, Wang S, Sun Y. 2011. Effects of astragaloside IV on IFN-gamma level and prolonged airway dysfunction in a murine model of chronic asthma. Planta Med 77: 328-333.

Zuhud EAM. 2007. Community attitude and Conservation: An analysis of Kedawung (Parkiatimoriana (DC) Merr.) as plant medicine stimuli for Comunity, Cases in National Park Meru Betiri, East Java. Disertation: Bogor Agricultural University. 